\title{
EARLY MARRIAGE ACCORDING TO ISLAMIC LAW
}

\author{
Delti Hidayati ${ }^{1}$, Nur Halimah Assa'diah ${ }^{2}$ \\ Sekolah Tinggi Agama Islam Assunnah, Medan, Indonesia
}

\begin{abstract}
Marriage is a form of worship, this is in line with the definition of marriage in the Islamic Law Compilation which reads; marriage is a very strong mitsaqan ghalizhan contract to obey Allah's commands and carry out it is worship. Religion and state also provide rules for marriage, especially at the age of the prospective husband and wife, so that it can be considered mature, with the aim of achieving sakinah mawaddah warahmah. However, there were several cases of underage marriage in Indonesia. And it is in the background of many factors and their respective goals. Among the factors are wanting to maintain religion, honor and achieve happiness and welfare. Such as the case of early marriage in the Tanjung Morawa area in Bangun Sari Village. They decided to get married because the candidates who came were people of good religion and morals, so that the married life they live is blessed according to their hopes and dreams.
\end{abstract}

\section{Keywords:}

Early marriage, Islamic law, Factor

\section{Abstrak}

Perkawinan merupakan salah satu bentuk ibadah, hal ini sejalan dengan definisi perkawinan dalam Kompilasi Hukum Islam yang berbunyi; Nikah adalah akad mitsaqan ghalizhan yang sangat kuat untuk menaati perintah Allah dan menjalankannya adalah ibadah. Agama dan negara juga memberikan aturan untuk menikah, terutama pada usia calon suami istri, sehingga dapat dianggap dewasa, dengan tujuan mencapai sakinah mawaddah warahmah. Namun, ada beberapa kasus pernikahan di bawah umur di Indonesia. Dan itu dilatarbelakangi oleh banyak faktor dan tujuan masingmasing. Diantaranya adalah keinginan untuk mempertahankan agama, kehormatan dan mencapai kebahagiaan dan kesejahteraan. Seperti kasus pernikahan dini di kawasan Tanjung Morawa di Desa Bangun Sari. Mereka memutuskan untuk menikah karena calon yang datang adalah orang-orang yang beragama dan berakhlak baik, sehingga kehidupan berumah tangga yang mereka jalani diberkati sesuai dengan harapan dan impian mereka.

Kata Kunci:

Pernikahan Dini, Hukum Islam, Faktor 


\section{A. INTRODUCTION}

$\mathrm{E}$ arly marriage is always associated with population, fulfillment of children's rights, and domestic violence. Indonesia is in the seventh rank of the country with the highest number of child marriages in the world. Every year in Indonesia 50,000 girls marry before the age of 16, One in six girls marry before they turn 18 , which is the minimum marriage limit recommended by international human rights bodies. ${ }^{1}$

Described in Article 6 paragraph 2 of Law no. 1 of 1974 that in order to marry someone who has not reached the age of 21 years must get permission from both parents. However, in practice, in society in general, there are still many who marry at a young age or underage. Nationally, early marriage under the age of 16 is $26.95 \%$. In fact, based on findings from Bappenas in 2008, it was stated that $34.5 \%$ of the 2,049,000 marriages in 2008 were married to minors. ${ }^{2}$

If you look at the definition of marriage and its purpose, then, in language terms, marriage means sexual relations, ${ }^{3}$ gather, unite, have intercourse and covenant. ${ }^{4}$ In terms of marriage, it means a contract (bond) which is based on the Shari'a which legalizes the husband and wife relationship between the two parties who have contracted. ${ }^{5}$

Bonds in marriage are very necessary for the fulfillment of basic psychological needs so that both individuals who have legalized their covenants and their children have a feeling of security and protection. ${ }^{6}$

Marriage according to Islamic law is marriage, which is a very strong contract or mitsaqan ghalidza to obey Allah's orders and carry out it is worship. ${ }^{7}$

In the sources of Islamic teachings, it is not found that the determination of the age limit for marriage in depth determines the age limit for maturity. This is a very important factor, because child marriage often occurs in girls. Even if Islam does not clearly define the boundaries, it does not mean that Islam absolutely allows underage marriages. ${ }^{8}$

From the theoretical point of view of marriage, a young couple can increase the form of family damage and weaken the relationship between husband and wife. They expect various pleasures after marriage. It turns out that they face many other

\footnotetext{
${ }^{1}$ Jewel Topsfiel and Amilia Rosa, https: // www. Matamatapolitik.com/m why- marriage- under-agerampant-in-Indonesia /. h 2. Downloaded on April 8, 2018

${ }^{2}$ Dwi Rifiani, Early Marriage in Islamic Law Perspective, Journal of Syari'ah, Volume 3 Number 2, December 2011, p. 126

${ }^{3}$ Abdullah bin Abdirrahmān bin sāaleh al-Bassām, Tauḍīhul Ahkām min Bulūghil Marām, juz v (Riyadh: dār Maimān, 2009), p 235.

${ }^{4}$ Mardani, Islamic Family Law in Indonesia (Jakarta: Kencana, 2017), p 23

${ }^{5}$ Sāleh bin Fauzān bin Abdullah al-Fauzān, Al-Mulakhkhaṡ al-Fiqh (Riyadh: Dār `ashimah, 1423 H ), p

${ }^{6}$ Singgih D. Gunarsa, Psychology for the family (Jakarta: PT BPK Gunung Mulia, 1995), p 25

${ }^{7}$ RI Department of Religion, Compilation of Islamic Law in Indonesia (Jakarta: RI Department of Religion, 2000), p 14

${ }^{8}$ Muhammad Ali Wafa, Critical Study of Marriage at a Young Age According to Islamic Law, Journal of Ahkam Volume 17, number 2, 2017, p. 391

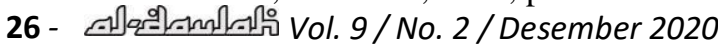


realities which are very contradictory to their previous experiences, causing many problems and unrest. ${ }^{9}$

This is a dilemma, where a person has to wait until a certain time to get married, until if someone is considered capable of carrying out the duties of husband or wife, on the other hand the stimuli and temptations are scattered everywhere. ${ }^{10}$

Based on the reality in people's lives that can be seen more and more clearly, the authors compile this mini research by presenting the factors that cause underage marriage, as well as the positive and negative impacts of underage marriage in the family, the law of underage marriage according to Islam both from al-Alquran and hadith, as well as the opinion of the 4 Imam Schools, then a little bit is presented about marriage laws in Indonesia. And the author raised this mini research with the title "Early Marriage According to Islamic Law"

\section{B. RESEARCH METHOD}

This research is a qualitative research with a field research approach. In which the researcher will go to the field to make observations about a phenomenon in natural conditions. In such a case, this approach is closely related to participatory observation. ${ }^{11}$

Qualitative research is a research of words and actions. ${ }^{12}$ Therefore, the author will use the analysis stages in the form of reading / observing data, analyzing and concluding; In this case the author will analyze the case or phenomenon of early marriage in the Tanjung Morawa area, Bangun Sari Village.

\section{RESULT \& DISCUSSION}

\section{Age of Marriage in Indonesia}

As previously explained, Indonesia is in the seventh level of countries with the largest number of child marriages in the world. Every year in Indonesia 50,000 girls marry before the age of 16 , one in six girls get married before they turn 18 , which is the minimum limit of marriage recommended by international human rights bodies. $^{13}$

Today, marriage is emphasized more on the purpose of sexual relations. It is not surprising that the absence of an age limit for people to marry becomes irrelevant. Nowadays marriage in Islam in general has been given guidance and practical instructions regarding the age requirements for someone who will carry out the level of marriage. ${ }^{14}$

\footnotetext{
${ }^{9}$ Ibid, p 392

${ }^{10}$ Ahmad Rofiq, Islamic Law in Indonesia, Cet IV (Jakarta: RajaGrafindo Persada, 2000) p 78.

${ }^{11}$ Lexy J. Moleong, Qualitative Research Methodology, (Bandung: Youth Rosdakarya, 2014), p. 26.

${ }^{12}$ Ibid, 157

${ }^{13}$ Jewel Topsfiel and Amilia Rosa, https: // www. Matamatapolitik.com/m why- marriage- under-agerampant-in-Indonesia /. h 2. Downloaded on April 8, 2018

${ }^{14}$ Wafa, Tela'ah Kritis......., p 391.
} 
Imam al-Shäfi'i divides three kinds in terms of the age of the prospective bride: (1) widow marriage, (2) adult girl marriage, (3) child marriage. For girls who are immature, the age limit is 15 years or have not had menstrual blood. A father can marry off without his permission beforehand on conditions that are favorable and not detrimental to the child. ${ }^{15}$

The state has clearly regulated the age limit for a person who wants to get married, which is stated in the Marriage Law number 1 of 1974, namely that the prospective husband is at least 19 years old and the prospective wife is at least 16 years old. ${ }^{16}$

When compared with the age limit for the prospective bride and groom in several Muslim countries, Indonesia is not the highest but also not the lowest. The following is the comparative data presented by Tahir Mahmood in personal law in Islamic countries. ${ }^{17}$

Comparison of Marriage Age Limits in Muslim Countries

\begin{tabular}{|l|c|c|}
\hline COUNTRY & MALE & FEMALE \\
\hline Aljazair & 21 & 18 \\
\hline Bangladesh & 21 & 18 \\
\hline Mesir & 18 & 16 \\
\hline Indonesia & 19 & 16 \\
\hline Irak & 18 & 18 \\
\hline Jordania & 16 & 15 \\
\hline Libanon & 18 & 17 \\
\hline Libya & 18 & 16 \\
\hline Malaysia & 18 & 16 \\
\hline Maroko & 18 & 15 \\
\hline Yaman Utara & 15 & 15 \\
\hline Pakistan & 18 & 16 \\
\hline Somalia & 18 & 18 \\
\hline Yaman Selatan & 18 & 16 \\
\hline Suriah & 18 & 17 \\
\hline Tunisia & 19 & 17 \\
\hline Turki & 17 & 15 \\
\hline
\end{tabular}

The determination of age limits in these Muslim countries, of course, has its own considerations. Especially Indonesia, which has revised the marriage law related to the age of marriage, namely article 7 of the Republic of Indonesia Law Number 16 of 2019 concerning Amendments to Law Number 1 of 1974 concerning Marriage, so that it reads; (1) Marriage is only permitted if the man and woman have reached the age of 19 (nineteen) years. (2) In the event of deviation from the age requirement as

\footnotetext{
${ }^{15}$ Khoiruddin Nasution, Indonesian Islamic Civil Code (Family) and Marriage Law Comparison in the Muslim World (Yokyakarta: ACAdeMIA + TAZAFFA, 2009), p. 372.

${ }^{16}$ RI Department of Religion, Compilation of Law ......., P 19.

${ }^{17}$ Ahmad Rofiq, Islamic Civil Law in Indonesia, (Jakarta: Raja Grafindo, 2013), p. 63.

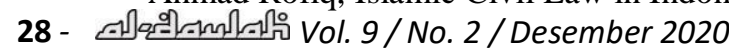


referred to in paragraph (1), the parents of the male and / or the parents of the female party can request dispensation to the court for very urgent reasons accompanied by sufficient supporting evidence.

The rules related to marriage have been regulated by the state, both in legislation and the Compilation of Islamic Law. Each chapter and article of the article describes the terms and conditions of marriage, as well as matters relating to the registration of marriage.

It is stated in Article $5 \mathrm{KHI}$, (1) In order to ensure orderliness of marriage for the Islamic community, every marriage must be recorded. (2). (2) The registration of marriage in paragraph (1) is carried out by a marriage registrar employee as regulated in Law No. 22 of 1946 and Law no. 32 of 1954.

Because in the beginning the Islamic Shari'ah-whether al-Qur'an or al-Sunnahdid not provide a concrete regulation regarding the registration of marriages. However, for the sake of orderliness these rules were enforced and several analyzes emerged according to Prof. Ahmad Rofiq stated that marriage registration is a provision that needs to be accepted and implemented by all parties. Because it has a fairly solid methodological foundation, namely qiyas or maslahat mursalah which according to al-Syathiby is a qath'I argument which is built on the basis of inductive study (istiqra'I). ${ }^{18}$

\section{Early Marriage According to Islam}

Regarding the age limit of marriage, Islam provides a very elastic limit so that it can apply to all places and times. ${ }^{19}$

Husein Muhammad in wafa said, classical fiqh books termed a young marriage with an-nikāh al-sंaghīr or al-sंaghīrah, the opposite is al-kabīr or al-kabīrah. In the new fiqh the term is al-zawāj al-mubakkir (young marriage). Marriage at a young age is a marriage between a man and a woman who is not yet mature, if baligh is determined by age or a count of years. So a young marriage is a marriage under the age of 15 according to the majority of jurisprudence experts or 18 years according to Abu Hanifah. ${ }^{20}$

According to Mawardi, underage marriage is marriage between a man and a woman who have not reached the age of 19 for men and 16 for women. Men who are over 19 years old with women under 16 years of age and marriages by men under 19 years old and women who are more than 16 years old. People who are not old enough to get married are required to apply for dispensation to marry at the local Religious Court. ${ }^{21}$

And based on Sarlito's opinion that the adult age limit for men is 25 years and for women 20 years, because a person's maturity is determined with certainty both by positive law and Islamic law. So it can be concluded that the age limit is said to be

\footnotetext{
${ }^{18}$ Ahmad Rofiq, Islamic Law in Indonesia, p. 102.

${ }^{19}$ Wafa, Critical Study......., p 394.

${ }^{20}$ Wafa, Critical Study......., p 393.

${ }^{21}$ Marmiati Mawardi, Problems of Underage Marriage, Journal "Analisa" vol 19 no 02 July-December
} 2012 
underage when a person is less than 25 years old for men and 20 years for women. ${ }^{22}$ According to the majority of scholars, the limitation for a person to get married when aqil baligh is, for men it is marked by a wet dream (ihtilam) and for women who are menstruating. The main problem faced by adolescents today is the fast pace of reproductive age. If a hundred years ago a woman had her first menstrual period (menarche) at the age of less than 17 years, now the average age for a woman to have her first period is 12 years old. The same thing happened to male adolescents. ${ }^{23}$

Az-Zuhaili said that jumhur fuqaha allowed the marriage of young girls by argument. $^{24}$

1. The explanation of " iddah little girl, that is for 3 months, in the word of Allah,

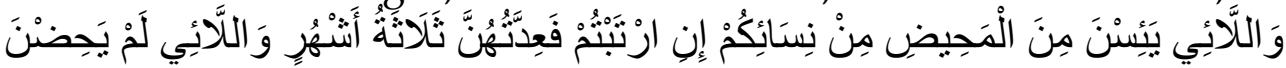

"And women who are no longer menstruating (monopause) among your women if you are in

doubt about their iddah period, then their iddah period is 3 months and so are women who don't menstruate." (ath-Talāq: 4).

Allah decreed iddah for a child who has not menstruated for three months like a woman who has had a monopouse. ${ }^{25}$

2. Marriage of the Prophet صلى الله عليه و سلم with Aisyah when she was 6 years old. This was reported by Aisyah Umm al-Mukminin in the hadith,

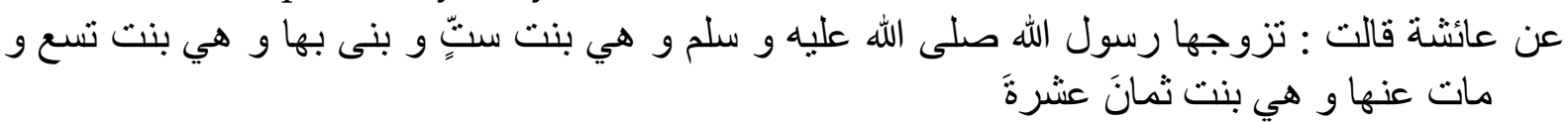

"From Ayesha she said that the Holy Prophet married her when she was 6 years old and mingled with her when she was 9 years old and died when she was 18 years old. ${ }^{26}$

3. Atsar friend. Ali married his daughter Umm Kulthum as a child to Urwah ibn alZubeir. Urwah ibn al-Zubeir married his nephew to his nephew when they were both young. A man donated his young daughter to Abdullah bin Hasan bin Ali, so Ali allowed this. Ibn Mas'ud's wife married her young daughter to Ibn Musayyab bin Nukhbah, Abdullah bin Mas'ud allowed this.

4. It could be that there is maslahah in marrying young children. Parents find equal partners for their children, so they don't wait until adulthood comes.

But Wafa did not agree with az-Zuhaili, he said the hadith about Ayesha's age when she was married to the Prophet Muhammad which was narrated by Muslims, it is only khabariyah about the Prophet's marriage. In the hadith there is no khithab (statement), either the khithab thalab that must be followed or the khithab al-tark that must be abandoned. Ibn Subrumah argued that it was an exception or special thing for the Prophet and could not be applied to his people. Thus, the age statement contained in the hadith cannot be concluded as the lowest age statement for marriage

22 Azlan, Thesis of Early Marriage According to Islam, UIN Sultan Syarif Kkasim, Pekan Baru Riau, 2010.

${ }^{23}$ Marmiati Mawardi, Problems of Underage Marriage..., p 204.

${ }^{24}$ Wahbah az-Zuhaili, Fiqih Islam wa Adillatuhu (Jakarta: Gema Insani, 2011),p 172.

${ }^{25}$ Jalalluddin Muhammad al-Mahalli dan Jalaluddin Abdurrahmān as-Suyuthi, Tafsir Jalalain (Surabaya: Pustaka eLBA, 2010), p 690.

${ }^{26}$ Muslim bin Hajjāj bin Muslim, Shahīh Muslim, Nikāh chapter, no 3482 (Riyadh: Dār al-Salām, 2000), p 597.

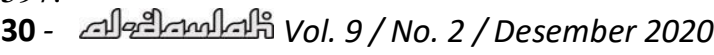


permits for women and men. Because the age limit is a matter of ijtihadiyah, which is to be given the opportunity to perform ijtihad at what age a person deserves to get married. ${ }^{27}$

Prophet Muhammad's hadith صلى الله عليه وسلم about the suggestion to young people who are able to get married to get married, as in the hadith narrated by Bukhariy:

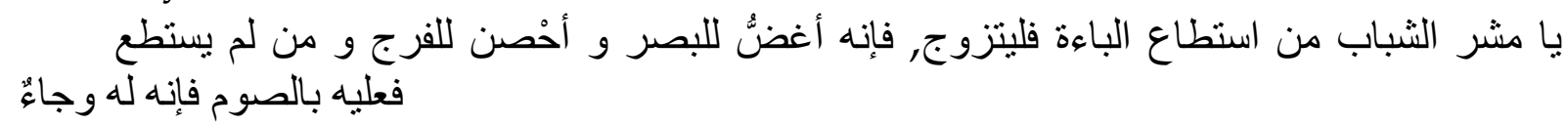

"O youths, whoever among you is ready to do a marriage, then marry because this marriage can look away and take care of his genitals and whoever is unable, then let him fast, because fasting weakens lust." 28

According to Wafa, this hadith provides several understandings: First, this hadith is an appeal to young people who are able to get married to get married, it does not mean limiting the age of marriage. Age in marriage is closely related to ability to act, because marriage is a legal act that requires responsibility and is burdened with certain obligations. Second, it provides an indication that a marriage can take place if a person already has a ba 'ah, what is meant by a ba ah is being able to have sex and being able to finance a marriage. ${ }^{29}$ Third, conclude that one of the main conditions for a marriage based on the Prophet's guidance, namely: have reached adulthood and have the ability to provide sufficient supplies both physically and materially for the cost of marriage and fostering a household. ${ }^{30}$

Early marriage in the view of the legal scholars is permissible, this ability can be read implicitly in the terms of male and female candidates. There are almost no fiqh books that require age, unless it is found in the laws of various Muslim countries. ${ }^{31}$ Ibn Hazm stated that it was permissible to marry underage girls, while boys were not allowed to be married until they reached maturity. ${ }^{32}$

Imam Nawawi رضي الله عنه in his sahih Muslim syarh explained that the Muslims have given permission to marry young girls / children and when they are grown / baligh there is no khiyar for fasakh for him according to Imam Malik and Imam asyShafi'i and the whole fuqaha Hijaz. Meanwhile, the Iraqi fuqaha'stated that he was allowed to perform khiyar if he had reached maturity. ${ }^{33}$

The vast majority of fiqh scholars legalize youth marriage, in a more popular term, underage marriage. According to them, for the problem of marriage the criteria of being baligh and sensible are not a requirement for legality. Some of the

${ }^{27}$ Wafa, Critical Study......h 395.

${ }^{28}$ Muhammad bin Ismā ìl al-Bukhāriy, Shah̄̄h al-Bukhāriy, no 5066 (Riyadh: Dār al-Salām, 1998), p 1101.

${ }^{29}$ Abu Malik Kamal bin al-Sayyid Sālim, Encyclopedia of Women's Fiqh (Bogor: Pustaka Ibnu Katsir, 2006), p. 217.

${ }^{30}$ Wafa, Critical Study......h 397.

${ }^{31}$ Ahmad Kusari, Marriage as a bond, (Jakarta: Rajawali Press), 1995, p. 34

${ }^{32}$ Wahbah az Zuhaili,al-Fiqh al-Islami wa adillatuhu, jilid IX (Bairut: Dar al-Fikr, 1989), p 6682.

${ }^{33}$ Desi Amalia, Jurnal Al-shari'ah, volume1, number 1, May 2017 
arguments stated above are as mentioned in the QS. At-Thalaq (4) and QS An-Nur (23)

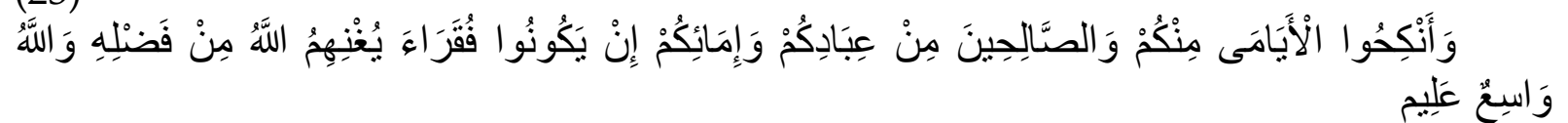

"And marry those who are alone among you, and those who are worthy (married) of your male servants and your female servants. if they are poor Allah will empower them with His gift. and Allah is vast (His gift), All-knowing.

Opinion of 4 Madzhab regarding underage marriage:

1. Madzhab Maliki

a. Can marry a little girl

b. Only her biological father, the person given the will, and the judge's guardian should marry the little girl.

c. If the little girl is an orphan, her consent is asked first.

2. Madzhab Hanafi

a. Can marry a little girl

b. Those who marry may be their father, grandfather, or other than the two of other relatives (guardians).

c. Sensible is not a condition of marriage for women.

3. Madzhab Hanbali

a. Can marry a little girl

b. Only her biological father, the person given the will, and the judge's guardian should marry the little girl.

c. If the little girl is an orphan, her consent is asked first

4. Madzhab Syafi'i.

a. It is possible to marry a little girl who is menstruating, if she is not menstruating, then she will be 9 years old

b. The only ones who marry the little girls are the real father and grandfather. ${ }^{34}$

3. Positive and Negative Impacts of Early Marriage

Early marriage in general will cause harm or negative impact, which occurs by women. Siti Musdah Mulia and friends convey some of the negative sides of early marriage as follows:

1. From a health perspective, pregnancy or giving birth to a child under the age of 20 is more vulnerable to the death of the infant and its mother. Healthy childbirth according to medical science is between the ages of 20-35 years.

2. From a physical perspective, young couples are still unable to be burdened with a job that requires physical skills to generate income that is sufficient for the family's needs.

3. From a mental perspective, a young partner is still not ready to be morally responsible for what they are responsible for.

4. From an educational perspective, efforts to mature marriage age are intended to obtain higher education which is more useful in preparing for the future. 
5. From a demographic perspective, early marriage is a period where fertility is high, so it does not support development in the welfare sector.

6. In terms of household continuity, early marriages are more vulnerable and prone to divorce considering that they are not stable, their level of independence is still low. ${ }^{35}$

The culture in most Indonesian society also views it as natural for marriage to be carried out at the age of children. According to Ratnariani in Waspada Online, at least there are several factors that cause it based on the results of a study of reports on cases of domestic violence, violence against women, violence against children, discourse, and research conducted by PKPA (Center for Child Studies and Protection), namely:

a. The view of a person's "maturity" from an economic perspective. When someone has been able to make money or has entered the productive work sector, it is considered mature and can get married, even though they are still children.

b. A person's maturity is seen from the physical changes, such as menstruation for girls and wet dreams for boys, followed by changes in the reproductive organs.

c. The occurrence of pregnancy outside of marriage, marriage is a solution that is often taken by families and communities to cover up disgrace and save the status of children after birth.

d. Victims of early marriage are more girls because economic independence, education status and women's capacity are not important things for the family. Because women are wives, all their individual needs and rights will be the responsibility of the husband.

e. The absence of criminal sanctions for violations of the Marriage Law, which means that parties who force marriage at an early age cannot be criminally handled.

In addition to the negative impact, early marriage also has a positive impact that can be obtained, provided that these positive benefits / values can only be felt by those who sincerely marry because of worship, among the benefits referred to are as follows:

1. Avoiding the perpetrator from sexual deviation. By getting married, they will be able to lower their eyes, so a married person will avoid the turmoil of lust, can easily maintain honor, and will not fall into the pit of heinous sin. Because sexual deviation (illegal sexual distribution) will cause various harms, both individually and socially. These deviations are adultery, homosexual, lesbian, masturbation or masturbation. Thus, marriage is an important means of extinguishing the fluctuation of lust, because if human lust has flared up and has not found a legal outlet, then the fluctuation of lust will seek an outlet for it which is haram with various kinds of immoral acts.

${ }^{35}$ Siti Musdah Mulia et al, Paving the Way of Human Early Life; Training Module for Trainers on Reproductive Rights in a Pluralism Perspective, Cet. I, (Jakarta: Institute for the Study of Religion and Gender (LKAJ), 2003), p. 79-80. 
2. Physically and psychologically healthy. Various surveys show that those who are married are more immune from diseases than those who are not married. Even those who are married if they are sick will recover faster than those who are still single. From a mental or spiritual perspective, those who are married are more able to control their emotions and sexual desires. This is in accordance with the hadith of the Prophet that marriage will maintain the view and faraj. plus if the couple already has children, the happiness of the husband and wife will be even greater.

3. Speed up having offspring. One of the goals of marriage is to get offspring, with early marriage it is possible to accelerate the birth of children. For a wife, in the age range of 20-25 years she will have a longer fertile period than women who are married over the age of 30 . with a longer fertile period is expected to get many offspring.

4. More value of worship. By getting married early, it will be faster to get the values of worship than delaying marriage. Because in Islam a household has a lot of charity land. For the husband to support his wife's children, providing spiritual support is a noble act, even categorized as jihad. Likewise a wife in providing food for her husband, welcoming his arrival after work and educating children will get abundant rewards.

5. Faster maturity. Getting married early will speed up someone reaching maturity. This is based on social reality which illustrates that in the life of a household there are many obstacles and obstacles. Those obstacles and obstacles if contemplated provide a good mental education. Those who are often hit by various difficulties will easily understand life. Because of that, the household can mature someone faster.

6. Useful for children's education. Husband and wife who marry at a young age are healthier, stronger and more fertile when they turn 40 years of age, at which time their children's education is in great need. Moreover, the slight difference between the ages of the two parents and their children will make it easier for both parents to be friends with their children, and it is easy for parents to know the nature and behavior of their children, which is an important element among the elements of education.

\section{CONCLUSION}

Descriptions of the profiles of two women who married can be seen in the following table:

\begin{tabular}{|c|c|c|c|}
\hline NO & INFORMATION & SUBJECT I & SUBJECT II \\
\hline 1 & Name & Um Hasan & Um Latif \\
\hline 2 & Marriage age & 16 & 16 \\
\hline 3 & length of marriage & 15 years & 13 Years \\
\hline 4 & Last education & SMA & D1 \\
\hline 5 & Address & T. Morawa, Bangun Sari & T. Morawa, Bangun \\
\hline
\end{tabular}

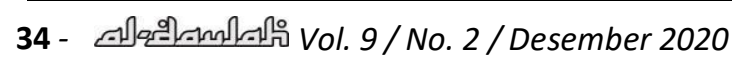




\begin{tabular}{|c|c|c|c|}
\hline & & Village & Sari Village \\
\hline 6 & Religion & Islam & Islam \\
\hline 7 & Position in the Family & House-wife & House-wife \\
\hline
\end{tabular}

After going through interviews with 2 women who decided to marry young, here are the reviews.

\section{Ummu Hasan}

She is one of the young mothers who chose to marry after a man arrived who according to her and her family was a man of religion and character. The prospective husband came to Umm Hasan's house with the aim of proposing, but Umm Hasan objected because she was still in high school. He is very respectful, according to his admission, many friends at his level have had the wrong association and some are pregnant outside of marriage.

When the prospective husband reads the hadith about "When you come to you people who are both religious and moral, then marry them, otherwise there will be damage to the face of the earth". Finally, Umm Hasan began to think and expressed her intention to accept the proposal to her parents, although she did not immediately accept the intention.

After undergoing a household dip, as a young mother who married at the age of 16 . He is a spoiled child because he is the youngest child, but over time he is able to mature, plus he already has the responsibility to educate his children. At the age of marriage, which has entered the 15th year of Umm Hasan, she is also optimistic that she wants to continue her education; after passing package $C$, he was interested in continuing to a higher level, he even actively participated in online learning classes. Umm Hasan also advised teenagers to take care of themselves and honor themselves, not being influenced by bad environments. He also does not recommend early marriage, if the candidate who comes is not a good person in terms of religion and morality.

2. Ummu Lathif

Not much different from the previous one, this mother of 4 children got married at a young age, namely 16 years. Now her marriage has entered the 13 th year. She decided to get married because the prospective husband who proposed to her was a person of good religion and character. Although at first the parents were surprised by the decision to marry, in the end, ummu Lathif got married without coercion or opposition from both sides of the family. The wedding took place in front of the witnesses and invited guests and was recorded at the KUA. He lived his married life happily and complemented each other, even he continued his education up to D1. All of that was based on his desire to protect himself, his religion and honor, as well as his practice of the Prophet's hadith:

$$
\text { وحسّنه الألباني) خطب إليكم من ترضون دينه وخلقه فزوجوه، إلا تفعلوا تكن فتتة في الأرض وفساد عريض (صحيح الترمذي }
$$

"If someone comes to you wanting to propose, someone you bless your religion and morals, then marry him, otherwise there will be slander on the face of the earth and 
widespread destruction."

From the presentation of the paper above, the following conclusions can be drawn:

1. Underage marriage is a marriage between a man and a woman who has not reached the age of 19 for men and 19 for women. Men who are over 19 years old with women under 19 years old and marriages by men under 19 years old and women who are over 19 years old.

2. In the source of Islamic teachings, it is not found that the determination of the age limit for marriage in depth determines the age limit for maturity. This is a very important factor, because child marriage often occurs in girls. Even if Islam does not clearly define the boundaries, it does not mean that Islam absolutely allows underage marriages. The arguments of the Qu'ran and hadith indicate that young marriages are carried out with noble intentions, worship and perfect religion, guard themselves and honor, already have the ability to ba'ah, then the family will receive blessings from Allah, "... if they are poor Allah will empower them with His gift and Allah is vast (His gift), All-Knowing". So from this it can be concluded to straighten out the paradigm that many people understand that; marrying young is not always a disgrace and not every disgrace is covered by marrying young is Islamic law.

3. When viewed from the classical jurisprudence law, there is no concrete age limit found, so that if a marriage is held, someone at a relatively young age will be valid according to religion if the harmonious conditions and conditions are met. However, state law regulates and states the minimum age limit for a person to marry; So that if there is a conflict when someone is married it becomes mandatory for him by reason of lust or other conditions that are considered dharuriy, then this has been offered the solution as referred to in paragraph (1), the parents of the male and / or the parents of the party. Women can ask for dispensation to the court with a very urgent reason accompanied by sufficient supporting evidence.

\section{E. ACKNOWLEDGMENT}

Such is the short research that the author can describe, perfection belongs only to Allah سبحانه وتعالى. And ofcourse the authors expect constructive criticism and suggestions for better writing and future research.

The author also hopes that a research will be held in which the object of research is a male couple who married young (husband).

\section{References}

Abdullah bin Abdirrahmān bin Ṣāleh al-Bassām, Tauḍ̄inul Ahkām min Bulūghil Marām, j. V Riyadh: Dār Maimān, 2009. 
Al-Bukhāriy, Muhammad bin Ismā'il, Shahīh al-Bukhāriy, no 5066, Riyadh: Dār alSalām, 1998.

Al-Fauzān, Sāleh bin Fauzān bin Abdullah, Al-Mulakhkhaṡ al-Fiqh, Riyadh: Dār 'Āshimah, $1423 \mathrm{AH}$

Al-Kuthbi, Moh Habib, The Impact of Underage Marriage on Domestic Relationships, Case Study in Purwodadi Village, Tepus District, Gunung Kidul Regency th. 2010-2013, Thesis, Yokyakarta: 2016.

Al-Mahalli, Jalalluddin Muhammad and Jalaluddin Abdurrahmān as-Suyuthi, Tafsir Jalalain, Surabaya: Pustaka eLBA, 2010.

Al-qurasyi, Isma'īl bin Katsir, Tafsīr Alquran al-`Ażīm, Riyadh: Maktabah Dār asSalām, 1998.

az-Zuhaili, Wahbah, Islamic Fiqh wa Adillatuhu Jakarta: Gema Insani, 2011.

RI Department of Religion, Compilation of Islamic Law in Indonesia, Jakarta: RI Department of Religion, 2000.

Gunarsa, Singgih D, Psychology for families, Jakarta: PT BPK Gunung Mulia, 1995.

Journal of Youth Studies vol. 3 no. 1, May 2014

Lutfiati, Dian, Health Research Methodology, Jakarta: Rineka Cipta, 2008.

Mardani, Islamic Family Law in Indonesia, Jakarta: Kencana, 2017

Mawardi, Marmiati, Underage Marriage Problems, Journal "Analisa" vol. 19 no. 02 July-December 2012.

Muslim, Muslim bin Hajjāj bin, Shahīh Muslim, chapter Nikāh, no 3482, Riyadh: Dār al-Salām, 2000.

Nasution, Khoiruddin, Indonesian Islamic Civil Code (Family) and Marriage Law Comparison in the Muslim World, Yogyakarta: Academia + Tazaffa, 2009.

Rofiq, Ahmad Rofiq, Islamic Law in Indonesia, Cet IV, Jakarta: RajaGrafindo Persada, 2000.

Sālim, Abu Malik Kamal bin al-Sayyid, Encyclopedia of Women's Fiqh, Bogor: Pustaka Ibnu Katsir, 2006.

Siti Musdah Mulia et al, Paving the Way of Human Early Life; Training Module for Trainers on Reproductive Rights in a Pluralism Perspective, Cet. I, (Jakarta: Institute for the Study of Religion and Gender (LKAJ), 2003), p. 79-80.

Topsfiel, Jewel and Amilia Rosa, https: // www. Matamatapolitik.com/m whymarriage- under-age-rampant-in-Indonesia /. h 2. Downloaded on April 8, 2018

Azlan, Thesis of Early Marriage According to Islam, UIN Sultan Syarif Kkasim, Pekan Baru Riau, 2010.

Wafa, Muhammad Ali, Critical Study of Marriage at a Young Age According to Islamic Law, Journal of Ahkam Volume 17, number 2, 2017. 